\title{
Trade Integration, Growth and Employment in West Africa: Implications for African Continental Free Trade Area (Afcfta)
}

Oluwafemi Mathew Adeboje ( $\boldsymbol{\sim}$ adebojeom@ndic.gov.ng )

Nigeria Deposit Insurance Corporation https://orcid.org/0000-0002-7490-6951

Abiodun Folawewo

University of Ibadan Department of Economics

Adeniyi Jimmy Adedokun

Dominican University

\section{Research}

Keywords:

Posted Date: March 1st, 2022

DOI: https://doi.org/10.21203/rs.3.rs-1031534/v1

License: (c) (i) This work is licensed under a Creative Commons Attribution 4.0 International License.

Read Full License 
TRADE INTEGRATION, GROWTH AND EMPLOYMENT IN WEST AFRICA: IMPLICATIONS FOR AFRICAN CONTINENTAL FREE TRADE AREA (AFCFTA)

\author{
Oluwafemi M. Adeboje ${ }^{+++}$, Abiodun O. Folawewo ${ }^{+}$and Adeniyi J. Adedokun ${ }^{++}$
}

${ }^{+++}$Oluwafemi M. Adeboje, Research, Policy \& International Relations Department, Nigeria Deposit Insurance Corporation (NDIC), femiadeboje@gmail.com; adebojeom@ndic.gov.ng

+ Abiodun O. Folawewo, Department of Economics, University of Ibadan, Ibadan, Nigeria, abiodun.folawewo@gmail.com

++ Adeniyi J. Adedokun, Department of Economics, Dominican University, Ibadan, Nigeria, ¡immyades2005@yahoo.com, adedokun.a@dui.edu.ng 


\title{
TRADE INTEGRATION, GROWTH AND EMPLOYMENT IN WEST AFRICA: IMPLICATIONS FOR AFRICAN CONTINENTAL FREE TRADE AREA (AFCFTA)
}

\begin{abstract}
This study investigated the effects of trade integration on economic growth and employment in West Africa from 2005 to 2019. Using a two-step panel GMM estimation technique, results showed that trade between West Africa member states and other SSA countries has more reinforcing growth propelling effect. That is, trade deepening between West African countries and other SSA countries has the tendency to boost growth more than when trade is just among the West African countries. Results also showed that although trade integration has not led to expansion in employment in the West African region, increased volume of trade among countries would foster more employment generation. The policy import of the study is threefold. First, when West Africa countries trade among themselves, the benefits of trade in enhancing economic growth and employment generation is small. Second, with trade between West Africa and other countries and regions in SSA, West Africa stands better chance of harnessing more growth and employment benefits from trade integration. Third, there is therefore the need for West Africa to key into the AfCFTA implementation as deeper trade within Africa has great potentials of fasttracking growth and more employment generation for the region.
\end{abstract}

\section{Introduction}

Economic integration is usually formed to foster economic cooperation among countries. Economic integration may be in the form of monetary or financial and trade union. Trade integration is the most common form of economic integration among countries within regions because it is less complex in implementation than monetary integration that requires convergence of many macroeconomic fundamentals, and other forms of economic integration (Flandreau and Maurel, 2001; Mongelli, 2008). Trade integration is aimed at eliminating trade barriers between member countries with the primary goals of enhancing economic growth and development. Empirical evidence has shown that trade integration promotes trade and competition, broadens market access, and enhances speed of economic growth and development (Vamvakidis, 1998; Levin, 2001; Ahmed, 2016; Soete and Van Hove, 2017; Ehigiamusoe and Lean, 2018; Park and Claveria, 2018).

Several regions of the world have established different forms of trade integration based on the perceived benefits of trade agreement. In Africa, several trade integrations have been formed over the years. The history of trade agreement started with the Organisation of African Unity (OAU) established in 1963 and later transformed into African Union (AU) in 2002, 
moving from Africa union of countries to union of people. On July 7, 2019, the continent launched the African Continental Free Trade Area (AfCFTA) agreement for the liberalization of trade in goods and services. The AfCFTA officially became operation on $1^{\text {st }}$ January 2020. Principal among the objectives of the agreement is the promotion of rapid economic growth and development within the African continent through intra-Africa trade boosting.

The developmental aspirations of African government from AfCFTA are akin to the World Trade Organisation (WTO) objectives of raising world's standards of living, ensuring full employment, fasting speed of economic growth and development ${ }^{1}$. However, economic unions and free trade areas in both advanced and emerging economies such as the European Union (EU) and North American Free Trade Agreement (NAFTA) have shown that benefits of integration are not automatic but predicated on prevailing macroeconomic environment of member countries. Over the years, increases in volume of trade in goods and services, and quantum of trade agreements have not resulted in much development across the world (Rodrik, 2001). According to Singh (2010), experiences of countries have shown that not all trade reforms have been as successful as anticipated.

The AfCFTA is envisaged not only to boost intra-regional trade, but also lead to increased production, thereby resulting in job creation especially for the bulging youth population in the African continent (UNECA, 2019). The AfCFTA operations are to leverage on the existing regional economic communities (RECs) on the continent. The Economic Community of West African States (ECOWAS) is one of the earliest RECs on the African continent. Since its establishment in 1975, ECOWAS has made tremendous progress in terms of trade integration through its Trade Liberalization Scheme (TLS) and Common External Tariff (CET) agreements among many regional schemes. The basic questions raised in the study, therefore are: what is the growth effect of trade integration in West Africa? What is the employment effect of trade integration in the region? And what are the implications of these for AfCFTA implementation? These questions are germane given the nature of economic growth that has not been able to lead to improved employment situation in a majority of the West African States over the years. As noted by Dudu (2018), economic integration has diverse effects on growth and employment across countries.

\footnotetext{
${ }^{1}$ https://www.wto.org/english/docs_e/legal_e/04-wto.pdf
} 
Consequently, this study investigates empirically the effect of regional trade integration on economic growth and employment in West African region between 2005 and 2019. Following Park and Claveria (2018), using intra-regional trade flows in goods and services among the ECOWAS member States and between these States and Sub-Saharan Africa Countries, we constructed a trade integration index for the region. Using a two-step panel GMM estimation technique on annual data for 2005 to 2019, our results showed that trade openness in general is growth enhancing. Trade between West Africa member states and other SSA countries has more reinforcing growth propelling effect. That is, trade deepening between West African countries and other SSA countries has the tendency to boost growth more than when trade is just among the West African countries. Results also show that although trade integration has not led to expansion in employment in the West African region, increased volume of trade among countries would foster more employment generation.

The rest of the paper is divided into five sections. Following the introduction, section 2 provides a description of trade, growth, and employment situations in West Africa. In section 3, brief review of relevant extant literature is done. Section 4 covers methodology and data, while discussion of empirical results is contained in section 5. Concluding remarks and policy implications of the study are given in section 6 .

\section{Trade Integration in West Africa Trade, Growth and Employment in West Africa}

\subsection{Intra-regional African Trade and ECOWA intra-regional Trade}

African trade has been tilted towards advanced countries of the North, with intra-regional African trade among countries been low over the years. This situation provides one of the basic reasons for the AfCFTA initiative. Trade between West African member States and other countries in Africa has similarly not been impressive over the years. The African Regional Integration Index (ARII) 2019 estimated the average intra-regional trade among countries in the continent to be $0.383^{2}$ (Figure 1). The degree of intra-regional trade in Africa varies across different Regional Economic Communities (RECs), with the Common Market for Eastern and Southern Africa (COMESA) having highest degree of intra-regional trade (0.445) and the

\footnotetext{
2 The ARII has five (5) basic components: trade integration; productive integration; macroeconomic integration; infrastructural integration; and free movement of people, with the trade integration being made of average tariff on imports, share of intra-regional exports/GDP, share of intra-regional imports/GDP, share of intra-regional goods trade, and signature and ratification of AfCFTA. The index ranges from 0 to 1 , with 0 being lack of integration and 1 most integrated.
} 
Southern African Development Community (SADC) with the least (0.340). Although the ECOWAS trade intra-regional trade index (0.438) is above the African average, it is still relatively low.

The average ECOWAS intra-regional trade integration shielded the divergent levels across the regional member States in terms of the components of the trade integration. The degree of aggregate trade integration is diverse and uneven among countries in West Africa with Côte d'lvoire having the highest of 0.772 followed by Togo with 0.58 , whilst Liberia had the least of 0.198, and four other countries (Cape Verde, Guinea, Guinea-Bissau, and Sierra Leone) falling below the sub-regional average of 0.438 (Figure 2). A closer look at the key elements of the trade integration reflects that the intra-regional imports for the sub-region (0.353) was greater than intra-regional exports $(0.295)$.

Despite long history of trade integration in the West African region, volumes of intraregional trade in goods and services among countries remained at low ebb. The ratio of exports among countries within the region to their total exports to the rest of the world rose slightly from 18.0 in 2010 to 21.7 percent in 2019, while intra-regional imports averaged 15.9 percent over the period (Figure 3). The general phenomenon of low intra-regional trade among West African countries, and between them and other SSA countries could be attributable to existence of several non-tariff barriers (NTBs) such non-tariff trade measures, infrastructural deficits (gaps), other trade-related transaction costs (inefficient regional transportation network and custom procedures, slow financial transaction clearance among others). In addition, exports are primarily directed to advanced and industrialized parts of the world. Production in the region was also subject to imported intermediate inputs derived from Europe, North America, and Asian countries.

\subsection{Economic growth and employment in West Africa}

The low level of intra-regional trade has been accompanied by relatively fair economic performance compared to other African regions. West African region witnessed consistent positive real per capita GDP growth since 2010 with a regional average of 2.3 percent in 2019, as 
against negative growth recorded in other sub-regions of Africa (Figure 4). The regional growth performance was due to sustained impressive growth in such countries as Cote d'Ivoire, Ghana, Guinea, Senegal, and Sierra Leone, among others (Figure 5).

The relative fair performance notwithstanding, growth was still low and not enough to bring about rapid development in the region. One major issue was the inability of economic growth to translate to improved employment generation as majority of countries in the region suffered from the 'Jobless growth syndrome' associated with many African and developing countries. Average employment-to-population ratio in West Africa hovered around 31.1 percent in 2019, which was below both the SSA and the entire African averages of 36.8 percent and 35.0 percent, respectively (Table 1). On the other hand, average employment growth in West Africa stood at 3.7 percent in 2019, a rate which was above the SSA (3.2) and Africa (3.0) averages. Across countries in West Africa, Liberia had the highest employment-to-population ratio of 43.8 and Senegal with the lowest of 24.3 in 2019 (Table 2). In terms of growth in employment, Nigeria had the highest of 4.4 percent while Cape Verde had the least of 1.9 percent.

\section{Literature Review}

Fundamentally, traditional trade theory such as Stolper-Samuelson and Heckscher-Ohlin, as well as the new trade theories have suggested that trade integration promotes economic growth and development through expansion in output and increased productivity resulting from comparative advantage and promotion of competition, and hence boost employment (Stolper and Samuelson, 1941, Balassa, 1961, 1980; Heckscher et al, 1991; Behagwatti, 1993; Park and Claveria, 2018). Because of the need for increase in output to meet up with trade responsibility, traditional trade theory found direct relationship between trade and growth. The validity of this theoretical postulation has been well investigated. Several empirical studies have identified and examined different kinds of integration such as economic, financial, and trade integration. The focus of this study is trade integration; thus, we review papers that investigate the nexus between integration and economic growth on one hand, and trade integration and employment on the other hand.

Common criticisms of majority of studies that have investigated the relationship between trade and economic growth centered around methodology, especially on the measurement of trade openness and integration, and estimation techniques employed. Also, conclusion of the various empirical studies has been mixed. Some are of the opinion that trade integration has 
significant positive relationship with growth. As market size increases, trade integration makes it possible for economies to maximize the benefits of diffusion of knowledge and technology, specialization and returns to scale (Deme and Ndrianasy, 2017; Balasubramaniam, Mansor and Puah, 2016; Nguyen 2015; Nwosu et al. 2013; Naveh, Torosyan and Jalaee, 2012; Almeida and Fernandes, 2008; Billmeier and Nannicini 2007; Bond, Jones and Ping, 2005; Badinger 2005; Baldwin, Braconier and Forslid, 2005; Lee, Antonio, and Rigobon., 2004; Alesina, Spolaore, and Wacziarg, 2000; Barro and Sala-i-Martin, 1997). On the other hand, the significant positive effect of trade could not be established (Ulasan, 2015; Golit and Adamu, 2014; Rodrik, 2006; Shafaeddin (2005); and Vanhoudt, 1999).

On the other hand, certain empirical evidence has shown that sources of growth are neutral, and the effectiveness of trade integration depends on factors such as policies, infrastructure, trade threshold, level of economic development, and quality of institutions (see Ogbuabor, et al., 2019; Zahonogo, 2017; Trejos and Barboza, 2015; Newfarmer and Sztajerowska, 2012; Kim and Lin, 2009; Brodzicki, 2003;). For example, while investigating the long-term effect of trade, Brodzicki (2003) found that economic integration only had positive long term growth effect but negative medium term growth effect. Also, Ogbuabor, et al. (2019) did not find any empirical evidence to support significant positive growth impact of regional economic integration in West African Economic and Monetary Union (WAEMU). However, the study argued that foreign direct investment (FDI) and institutional quality were the channels through which WAEMU integration could impact on growth.

According to UNCTAD (2013), the link between trade and employment is complex. Several channels through which trade affects employment have been identified. Some studies established the growth channel. That is, as trade improved growth, it resulted in employment generation as more people were needed to boost production of goods and services. There are also other side of the argument. In the instance of jobless growth, lopsided trade may not increase employment significantly. For instance, most of the developing countries that have been recording consistent significant growth over time have also been battling with the problem of high unemployment. Thus, the argument in the literature moved from ordinary growth to productivity growth. However, this also has its own shortcoming as increase in labour productivity reduces labour needed to produce same level of output. 
Empirical studies have shown that there are several factors responsible for employment figures across countries. Thus, it becomes exceedingly difficult and complex to disentangle the effect of trade openness. For instance, McMillan and Verduzzo (2011) found no correlation between trade liberalization and industrial employment for many developing countries. OECD (2007) in its report stated that imports have more positive impact on employment in the long run than in the short run, particularly when such importation are related to infrastructure equipment and production. In another view, because displaced workers from import competing industries are not easily absorbed by the exporting industries, Hoekman and Winters (2005) concluded that the direct effect of trade developments on aggregate employment is subdued. The position of Hoekman and Winters (2005) is consistent with the earlier work of Edwards and Edwards (1996), where they opined that affected sectors due to increase in openness would initially experience increase in unemployment. However, they believed that the gravity of unemployment would depend on degree of import penetration.

On methodological ground, several arguments have been put forward in the literature on weaknesses of various proxies that have been used for trade integration. One of the latest studies that tried to employ a more comprehensive index is Park and Claveria, (2018). The study developed multidimensional regional integration index (MDRII) to capture economic integration. The MDRII encompasses six basic dimensions of regional integration: trade and investment; money and finance; regional value chains; infrastructure and connectivity; movement of people; and institutional and social integration.

Given the above, it is cleared that the discourse on the effect of trade integration on growth and employment is inconclusive. Several reasons have been attributed to this, including proxies used for trade integration, estimation techniques employed, and model variables of choice. This study contributes to existing stock of knowledge on trade integration, growth and employment with a particular focus on West Africa.

\section{Methodology and Data}

\subsection{Trade Integration Index}

The index used in this study follows Park and Claveria (2018), where the Multidimensional Regional Integration Index (MDRII) was constructed. The MDRII is a composite index that encompasses the fundamental indicators of regional integration. Its series encompasses basic 
aspects of regional integration such as trade and investment, money and finance, regional value chains, infrastructure and connectivity, movement of people, and institutional and social. However, because the scope of this study is to investigate the growth and employment effect of trade integration, this study adopts a variant of the trade and investment regional integration index in the MDRII. We aggregate the first three of the five components of trade and investment integration, namely: proportion of intraregional goods exports to total good exports, proportion of intraregional good imports to total goods imports, intraregional intensity index, proportion of intraregional foreign direct investment (FDI) inflows to total FDI inflows, proportion of intraregional FDI inflows plus outflows to total FDI inflows plus outflows (see Table A1). This modification is necessary to separate trade variables from investment variables. By doing this, the specific objective of investigating the effect of trade integration on growth and employment can be achieved. Each of the indicators is computed for the 15 West African countries across the period 2005-2019. The indicators are largely sourced from International Monetary Fund (IMF) Direction of Trade Statistics.

The three indicators are aggregated into a single composite index using panel principal component analysis (PCA). PCA is superior to a simple average method since it assigns relevant weights to each of the indicators, and it is specifically relevant when each indicator measures different component of a single composite index. According to Park and Claveria (2018), PCA is suggested for indicators ranging from 3 to 10, thus the use of PCA is relevant in this study since

the indicators are 3 in number. Furthermore, the use of PCA is premised on our preliminary analysis of the rejection of the null hypothesis that the individual components are not correlated. We found a correlation of at least 0.5 among the individual indicators.

\subsection{Model Specification and Estimation Technique}

This study aims to investigate the effects of trade integration and each of its components on economic growth and employment. The model for this study follows Vamvakidis (1998) and Park and Claveria (2018). Economic growth and employment are the dependent variables of interest for each of the respective models while the explanatory variable is the computed trade integration index (MDRII), including each of its three indicators earlier mentioned. However, other control variables that influence growth and employment, in line with extant literature, are 
included in the model. Computation and description of variables of the empirical models are given in Table 3.

Following Romer (1990) and Barro (1999) the growth model is specified as:

$$
y_{i t}=\alpha_{0}+\alpha_{1} y_{i_{, t-1}}+\alpha_{2} X_{i, t}+\alpha_{3} T_{R I I} I_{i, t}+v_{i t}
$$

Where $y_{i, t}$ is the logarithm of GDP per capita for country $i$ at time $t, y_{i, t-1}$ is the lagged logarithm of GDP per capita, $X_{i, t}$ is a vector of control variables (listed in Table A1), TRII $i, t$ is the computed trade integration index. The composite error term $v_{i t}$ consists of two components, $\mu_{i}$ which is the cross-section, or individual-specific error component, and $\varepsilon_{i, t}$ which is the combined time series and cross-section error component. That is, $v_{i t}=\mu_{i}+\varepsilon_{i, t}$.

Similarly, following Folawewo and Adeboje (2017), the baseline panel model for employment is:

$$
e m p_{i t}=\alpha_{0}+\alpha_{1} e m p_{i, t-1}+\alpha_{2} \text { wage }+\alpha_{3} X_{i, t}+\alpha_{4} \text { TRII }_{i, t}+\mu_{i}+\varepsilon_{i, t}
$$

Where empit is the employment rate for country $i$ at time $t$ while $e m p_{i, t-1}$ is the lagged employment rate. The data are largely sourced from World Bank World Development Indicators (WDI) database for the period of 15 years from 2005 to 2019.

As a means of addressing the inherent issues associated with panel data analysis, like observed heterogeneity across countries, dependent variable persistence, and endogeneity among others, this study employed a two-step System Generalized Method of Moments (GMM) which was proposed by Areliano and Bover (1995) and Blundell and Bond (1998). The system GMM gives a more consistent and efficient estimates, and also checks for the robustness of errors that are correlated between past and present. Unlike the Ordinary Least Squares (OLS), the System GMM also controls the inconsistency and biasness which can cause omission of unobserved time-invariant country effect (Blundell et al, 2001).

\section{Discussion of Result}

Analysis of impact of trade integration on economic growth and employment is done at two levels. First, we investigate the effect of trade integration among West Africa member states; second, the impact of trade integration between West African member States and other SSA countries is analysed. This enables us to compare the differential impacts of regional trade 
integration within West African region and the larger African continent to reflect the context of the AfCFTA implementation by countries within the region.

\subsection{Trade Integration and Growth}

Empirical result of the growth model is presented in Tables 3. In column 1, which is the baseline regression model, only the control variables are included in the regression model as explanatory variables, while the composite trade integration index enters to the baseline model in column 2. In column 3, the baseline model is augmented by including all the components of the composite trade integration index simultaneously, excluding the composite index, while in columns 4-6, each of the components enter the model separately. The different levels of regression analyses are carried out to investigate the respective impact of each of the regional integration indicators employed in this study on economic growth, proxied by log of real GDP per capital.

In column 1, which only includes all the control variables as the baseline regression, trade openness has a significant and positive impact on growth. This is in line with the a priori expectation and the large body of existing empirical and theoretical literature that free trade and growth are positively correlated since open trade allows countries to have greater technological spillovers and thus facilitate faster economic growth (Levine and Renelt 1992, Ben-David 1993, Barro and Sala-I-Martin 1995, Vamvakidis, 1998). It is worthy to note that, in this regard, the trade openness is the nondiscriminatory openness.

In column 2, the baseline regression model is augmented by the inclusion of the multidimensional composite trade integration index (MDRII) as part of the regressors. Contrary to theoretical postulate, the composite trade integration index has insignificant negative impact on growth. One reason that could be adduced to the observed phenomenon is the existence of low level intra-regional trade among the West African countries, coupled with the natured of products being traded. This becomes more obvious when it is discovered that even with the inclusion of the composite index in the model, trade openness maintains its significant positive effect. When the three components of the composite trade integration index - import, export and trade intensity index are included, result also show that each of the components has negative but insignificant relationship with economic growth (Column 3). The analysis becomes more interesting and revealing when each component of trade integration index is included in the growth model separately, in which case, the sign of their relationship with growth change from 
negative to positive (columns 4-6). This implies that imports, exports and trade penetration among the West African countries have tendency to promote economic growth in the region.

For the control variables, previous level of growth, investment and inflation rate have positive impact on current growth performance. That is, the degree of current economic performance has positive influence on next period performance, investment acts as impetus for spurring economic growth, and that certain level of inflation might be necessary for the economy. On the other hand, both government consumption and control of corruption have negative effect on economic growth. The growth reducing effect of government consumption could be attributable to the fact that such consumption expenditure might not be for productive purpose, while corruption hinders growth.

The results of the counterfactual analysis of intra-regional trade between West African member states and other SSA countries (Table A2) further emphasize the growth propelling effect of trade openness in general. As with the case of the intra-regional trade within West Africa, the overall composite trade integration index, has negative but insignificant effect on economic growth. When all the three components of the trade integration index are introduced to the growth model (column 3), trade openness and export have -an insignificant but positive relationships with growth, and indications of the potential of intra-regional export to induce economic growth in the region. Conversely, when each of the components is used independently, they yield negative effect (column 4-6).

Overall, our findings reveal that, trade openness in general exerts tremendous enhancing effect on economic growth in the West Africa region. The low proportion of intra-regional trade among members compared to volume of their trade with rest of the world notwithstanding, import, exports and trade intensity are found to prosper growth independently, though the composite trade integration index does not. Since AfCFTA is meant to remove trade barriers among African countries, hence, boost intra-regional imports and exports, the agreement has great potentials for facilitation of growth especially in West Africa.

\subsection{Trade Integration and Employment}

The empirical results of the employment regression models are shown in Tables 4 and Table A3. The baseline specification (column 1) and the other five augmented specifications (columns 2 to 6) are presented in each of the respective tables. 
From the baseline model (column 1), it is shown that previous period level of employment significantly influences the current level. This is normal and not unexpected as the prevailing (un)employment condition gives a signal of labour market environment. The real GDP per capita exerts a negative but insignificant impact on employment in the region. Although this is contrary to the a priori expectation, this could possibly explain the 'jobless growth' phenomenon in the region in which the growth in the economy could not translate to enough employment generation (Herman, 2012). Thus, this underscores the need for sustained economic growth that can exceed the combined growth rates of labour force and productivity such that employment could be guaranteed in the long run (Levine, 2013; Folawewo and Adeboje, 2017). Wage has significant negative relationship with employment in the West African region. Ordinarily, wage (being the price of labour) and employment (being the demand for labour) should exhibit negative relationship.

The results of impact of trade on employment show that trade has not been able to promote employment in the West African region. In the baseline model, trade openness has an insignificant reducing effect on employment. When the baseline model is augmented with the multidimensional regional integration index (MDRII), the relationship between trade openness and employment changes to positive, with that of MDRII being negative (column 2). Across all the models, both imports and exports exert negative impact on employment. Of importance is the employment enhancing effect of trade intensity index when the index alone is included in the baseline model (column 6). This reflects that increase in the degree of trade among countries would lead to creation of more jobs and boost employment in the region. The results of the counter-factual analyses using trade between West African and other parts of SSA are not different from when the trade is among the West African countries (Table A2). However, when all the components of trade integration are introduced in the model (column 3), trade openness, imports and trade integration all have insignificant positive effect on employment. This is an indication that trade deepening beyond West Africa to other SSA regions has huge potentials for leading to increase in employment in West African member states, which emphasizes the potential employment benefit of AfCFTA implementation.

An important implication of the results is the potential of trade integration for boosting employment in the region provided the current nature of trading in raw and unprocessed primary products changed to that of value-added and semi-products goods. This will not only raise the 
level of trade among the countries within the region, but also lead to increase trade between these countries and others in Africa at large. This will shift the current trend of heavy importation from and exports to other regions of the world.

\section{Conclusion}

Trade openness and integration among countries have been touted to promote economic growth and employment, hence enhance development. This justifies why many countries have come together to form trade union and trade area agreements. African countries are not left behind in this euphoria of benefits for trade, with the launch of the AfCFTA in July 2019 and with the effective commencement of implementation in January 2020. Before the launch of AfCFTA, West Africa countries already embarked on aggressive regional trade integration within the ECOWAS platform. It is noted that despite the trade integration efforts, the level of economic growth and employment in the region is still low. Consequently, we investigated the effects of trade integration on economic growth and employment in West Africa and based on our results draw implications for the AfCFTA implementation.

Using a two-step panel system GMM estimation technique on annual data for 2005 to 2019, our results showed that trade openness in general was growth enhancing. It is also found that although trade integration as a whole did not promote growth, its components - imports, exports and the degree of trade penetration among the West African countries had tendency to promote economic growth in the region. More so, trade between West Africa member states and other SSA countries had more reinforcing growth propelling effect. In terms of employment effect of trade integration, we found that trade had not led to expansion in employment in the West African region. However, our results revealed that increased volume of trade among countries would foster more employment generation. The opportunity of more intra-regional trade presented by AfCFTA agreement, therefore, poses as an advantage for improved economic growth and increase employment in the West Africa countries.

The policy import of the study is threefold. First, when West Africa countries trade among themselves, the benefits of trade in enhancing economic growth and employment generation is small. Second, with trade between West Africa and other countries and regions in SSA, West Africa stands better chance of harnessing more growth and employment benefits from trade integration. Third, there is therefore the need for West Africa to key into the AfCFTA 
implementation as deeper trade within Africa has great potentials of fast-tracking growth and more employment generation for the region.

\section{Declarations}

\section{Availability of Data and Materials}

The datasets employed for this study are available from the corresponding author on request.

\section{Competing Interests}

Not Applicable

\section{Funding}

Not Applicable

\section{Authors' Contribution}

All the authors contributed to the interpretation of the empirical results and critical revision of the article.

Author 1 (Dr. Oluwafemi M. Adeboje) performed the data collection, data/empirical analysis and wrote the methodology section.

Author 2 (Professor Abiodun O. Folawewo) conceived the paper, wrote the introductory part of the paper and some part of Section 2. He also approved the final version sent for publication. Author 3 (Dr. Adeniyi J. Adedokun) wrote the literature review and some part of Section 2.

\section{Acknowledgements:}

The authors are grateful to the Managing Editor and anonymous peer reviewer for adding to the quality of the manuscripts through their insightful comments.

\section{References}

Ahmed, A. (2016). Integration of financial markets, financial development and growth: Is different? Journal of International Financial Markets, Institutions and Money, 42 (2):4359 
Alesina, A., Spolaore, E., and Wacziarg, R., (2000). Economic integration and political disintegration. American Economic Review 90 (5), pp. 1276-1296

Almeida, R., and Fernandes, A. (2008). Openness and technological innovations in developing countries: evidence from firm-level surveys. Journal of Development Studies. 44 (5), 701-727.

Areliano, M. and Bover, O. (1995). Another Look at the Instrumental Variable Estimation Of Error-Components Models. Journal of Econometrics 68: 29-5

African Union, African Development Bank, and Economic Commission for Africa (AU-AfDBECA). (2019). Africa Regional Integration Index (ARII) 2019

Badinger, H. (2005). "Growth Effects of Economic Integration: Evidence from the EU Member States." Review of World Economics 141 (1):50-77.

Balassa, B. (1961). The Theory of Economic Integration. Homewood: R.D. Irwin.

-. (1980). The Process of Industrial Development and Alternative Development Strategies. Essays in International Finance No. 141, Princeton: University Princeton

Balasubramaniam, A., Mansor, S.A., and Puah, C. (2016). The Relationship between Trade Integration and Economic Growth: Case of ASEAN-5 Countries. Global Economy Journal Vol. 16 (4), pp 745-768

Baldwin, R.E., Braconier, H., and Forslid, R. (2005). Multinationals, endogenous growth, and technological spillovers: theory and evidence. Review of International Economics 13 (5), 945-963.

Barro, R.J., and Sala-i-Martin, X. (1995). Economic Growth. New York: McGraw-Hill, Inc.

-. (1997). Technological diffusion, convergence, and growth. Journal of Economic Growth 2 (1), $2-26$.

Barro, R. J. (1999). "Determinants of Economic Growth: Implications of the Global Evidence for Chile", Cuadernos de Economia, 36 (107): 443-478.

Ben-David, D. (1993). Equalizing Exchange: Trade Liberalization and Income Convergence. Quarterly Journal of Economics, 108:653-79.

Bhagwati, J. (1993). "Regionalism and multilateralism: an overview". In J. de Melo and A. Panagariya, eds., New Dimensions in Regional Integration, Cambridge: Cambridge University Press, pp.22-51.

Billmeier, A., \& Nannicini, T. (2007). Trade openness and growth: pursuing empirical glasnost. IMF Working Paper, WP/07/156.

Blundell, R. and Bond, S. (1998). Initial Conditions and Moment Restrictions in Dynamic Panel Data Models. Journal of Econometrics, 87: 115-143.

Blundell, R., Bond, S. and Windmeijer, F. (2001). "Estimation in dynamic panel data models: Improving on the performance of the standard GMM estimator". In Baltagi, B.H., Fomby, T.B. and Carter Hill, R. (Ed.) Nonstationary Panels, Panel Cointegration, and Dynamic Panels (Advances in Econometrics, Vol. 15), Emerald Group Publishing Limited, Bingley, pp. 53-91

Bond, E.W., Jones, R.W., and Ping, W. (2005). Economic takeoffs in a dynamic process of globalization. Review of International Economics 13 (1),1-19.

Brodzicki, T. (2003). "In Search for Accumulative Effects of European Economic Integration."Paper presented at the 2nd annual conference of the EEFS, Bologna, University of Bologna, May 2003. 
Deme, M. and Ndrianasy, E.R. (2017). Trade-creation and trade-diversion effects of regional trade arrangements: Low-income countries. Applied Economics 49(22), 2188-202.

Dudu, S. (2018). Economic and social effects of labour mobility in the European Union. Economics and Social Sciences, University of Seville, Seville, Spain.

Ehigiamusoe, K. U. and Lean, H.H. (2018). Do economic and financial integration stimulate economic growth? A critical survey. Economics Discussion Papers, No. 2018-51, Malaysia: Kiel Institute for the World Economy.

Edwards, C. A. and Edwards, S. (1996). 'Trade Liberalization and Unemployment: Policy Issues and Evidence from Chile', Cuadernos de Economía, Año 33, 99: 227-250.

Folawewo, A.O. and Adeboje, O. M. (2017). Macroeconomic Determinants of Unemployment: Empirical Evidence from Economic Community of West African States. African Development Review, 29 (2): 197-210.

Golit, P.D. and Adamu, Y. (2014). Regional integration models and Africa's growth in the 21st century: A fitness evaluation. African Development Review 26(S1), 111-21.

Heckscher, E. F., Ohlin, B., Flam, H., \& Flanders, M. J. (1991). Heckscher-Ohlin trade theory. Cambridge, Mass, MIT Press.

Herman, E. (2012). The Influence of the Economic Growth Process on Romanian Employment. Economics and Applied Informatics, 18(1): 5-12.

Hoekman B and Winters, A. (2005). Trade and employment: Stylized facts and research findings. Policy Research Working Paper 3676. World Bank.

Kim, D.H., Lin, S.C. (2009). Trade and growth at different stages of economic development. Journal of Development Studies, 45 (8), 1211-1224

Lee, H. Y., Antonio, R. L., \& Rigobon, R. (2004). Once again, is openness good for growth? Journal of Development Economics, 75(2), 451-472.

Levin, R. (2001). International financial liberalization and economic growth. Review of International Economics, 9 (3):688-702.

Levine, L. (2013). Economic Growth and the Unemployment Rate', Congressional Research Service Report R42063, 1-10.

Levine, R., and Renelt, D. (1992). A Sensitivity Analysis of Cross-Country Growth Regressions. American Economic Review, 82:942-63.

McMillan, M. and Verduzco, I. (2011). New evidence on trade and employment: An overview. In: Jansen M, Peters, R and Salazar-Xirinachs, J. M eds. Trade and Employment, From Myths to Facts. ILO, Geneva: 23-60

Naveh, M.H., Torosyan, T. and Jalaee, S. A. (2012). Regional economic integration and its effects on economic growth and economic welfare. World Applied Sciences Journal 17(10), 1349-55.

Newfarmer, R. and Sztajerowska, M. (2012). Trade and Employment in fast-Changing World. In: Lippoldt, Douglas (Ed.), Policy Priorities for International Trade and Jobs. OECD, Paris, pp. 7-73

Nguyen, V.C. (2015). The impact of trade facilitation on poverty and inequality: Evidence from low-and middle-income countries. The Journal of International Trade \& Economic Development 24(3), 315-40.

Nwosu, O.E., Orji, A., Urama, N., and Amuka, J. I. (2013). Regional integration and foreign investment: The case of ASEAN countries. Asian Economic and Financial Review 3(12), $1670-80$ 
Ogbuabor, J. E., Anthony-Orji, O. I., Ogbonna, O. E., and Orji, A. (2019). Regional integration and growth: New empirical evidence from WAEMU. Progress in Development Studies, pp. 1-21

Organization for Economic Cooperation and Development (OECD) (2007). OECD Employment Outlook 2007. Paris

Park, C. and Claveria, R. (2018). Does regional integration matter for inclusive growth? Evidence from the multidimensional regional integration index. ADB Economics Working Paper Series, Manila, Philippines: Asian Development Bank

Rodrik, D. (2006). Goodbye Washington consensus, hello Washington confusion? A review of the World Bank's economic growth in the 1990s: learning of the decade reform. Journal of Economic Literature, XLIV, 973-987.

- . (2001). The Global Governance of Trade as if Development Really Mattered. A paper prepared for UNDP, Harvard University.

Romer, P. M. (1990). Endogeneous technical change. Journal of Political Economy, 98(2), 71102.

Shafaeddin, S. M. (2005). Trade liberalization and economic reform in developing countries: structural change or de-industrialization. Discussion papers, UNCTAD, Geneva.

Singh, T. (2010). Does international trade cause economic growth? A survey. World Econ., 33(11). pp. 1517-1564.

Soete, S. and Van Hove, J. (2017). Dissecting the trade effects of Europe's economic integration agreements. Journal of Economic Integration, 32 (2): 193-243.

Stolper, W. F. and Samuelson, P. (1941). Protection and Real Wages. Review of Economic Studies, 1941, vol. 9, issue 1, 58-73.

Trejos, S., and Barboza, B. (2015). Dynamic estimation of the relationship between trade openness and output growth in Asia. Journal of Asian Economics, 36 (2015), 110-125.

Ulaşan, B. (2015). Trade openness and economic growth: panel evidence. Applied Economics Letters 22 (2), 163-167.

United Nations Conference on Trade and Development (UNCTAD). (2013). The impact of trade on employment and poverty reduction. United Nations TD/B/C.I/29

United Nations Economic Commission for Africa (UNECA). (2019). African Continental Free Trade Area: Questions and Answers. UNECA, Addis Ababa. https://hdl.handle.net/10855/43233

Vamvakidis, A. (1998). Regional integration and economic growth. The World Bank Economic Review, 12 (1):251-270.

Vanhoudt, P. (1999). "Did the European Unification Induce Economic Growth? In Search of Scale Effects and Persistent Changes." Weltwirtschaftliches Archiv 135 (2):193-220.

Zahonogo, P. (2017). Trade and economic growth in developing countries: Evidence from subSaharan Africa. Journal of African Trade 3, pp. 41-56.

Flandreau, M. and Maurel, M. (2001). Monetary Union, Trade Integration, and Business Cycles in 19th Century Europe: Just Do It. Centre for Economic Policy Research, Discussion Paper No. 3087. CEPR: London, UK.

Mongelli, Francesco, P. (2008). European Economic and Monetary Integration and the Optimum Currency Area Theory. Economic Paper 302, European Commission, Brussel. 
Figures

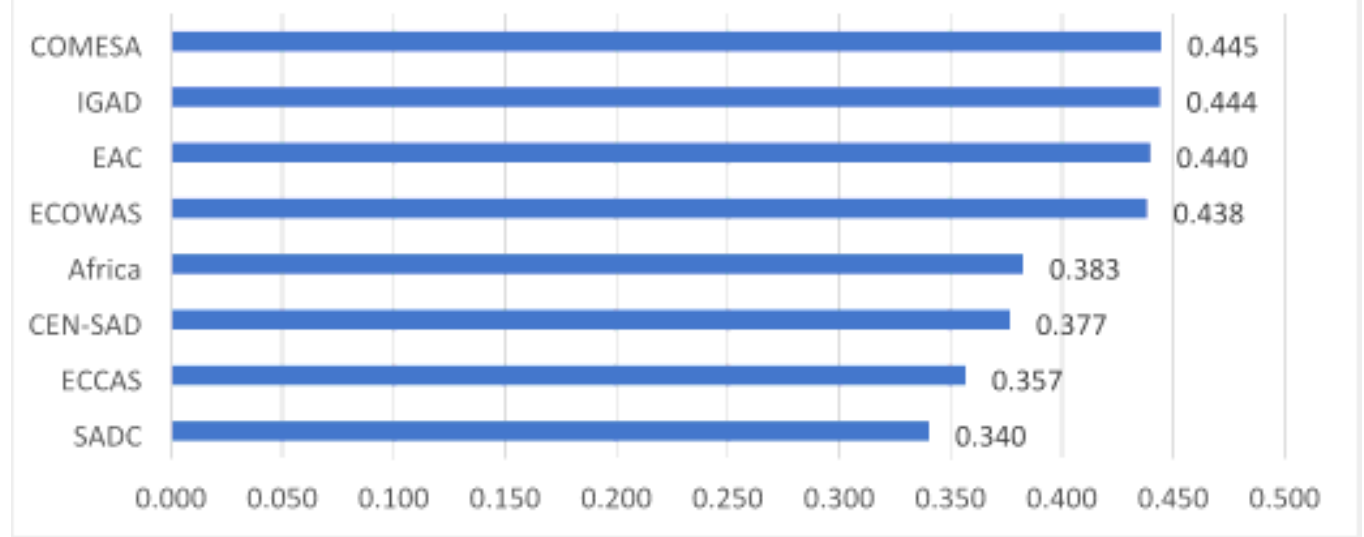

\section{Figure 1}

Intra-regional trade in Africa, 2019

Source: Source: AU-AfDB-ECA, African Regional Integration Index 2019

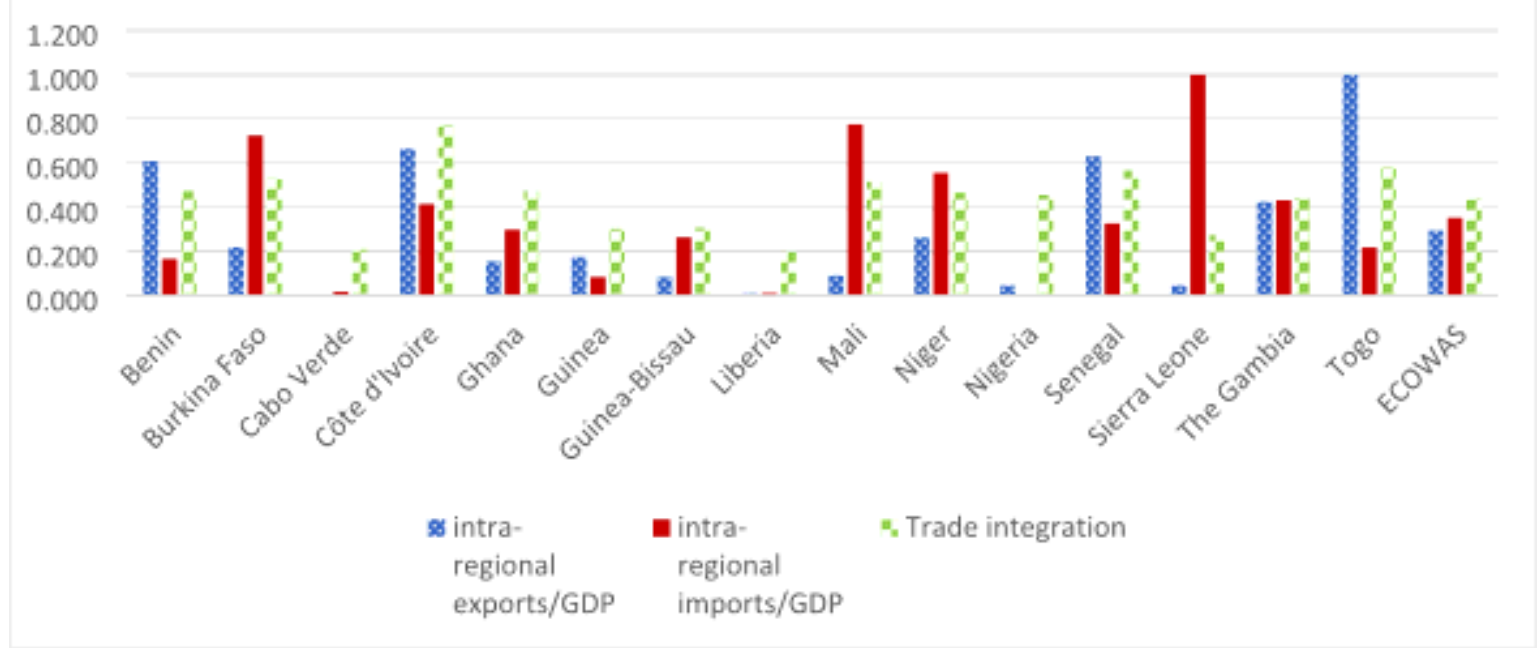

Figure 2

Intra-African Regional Trade in ECOWAS

Source: Source: AU-AfDB-ECA, African Regional Integration Index 2019 


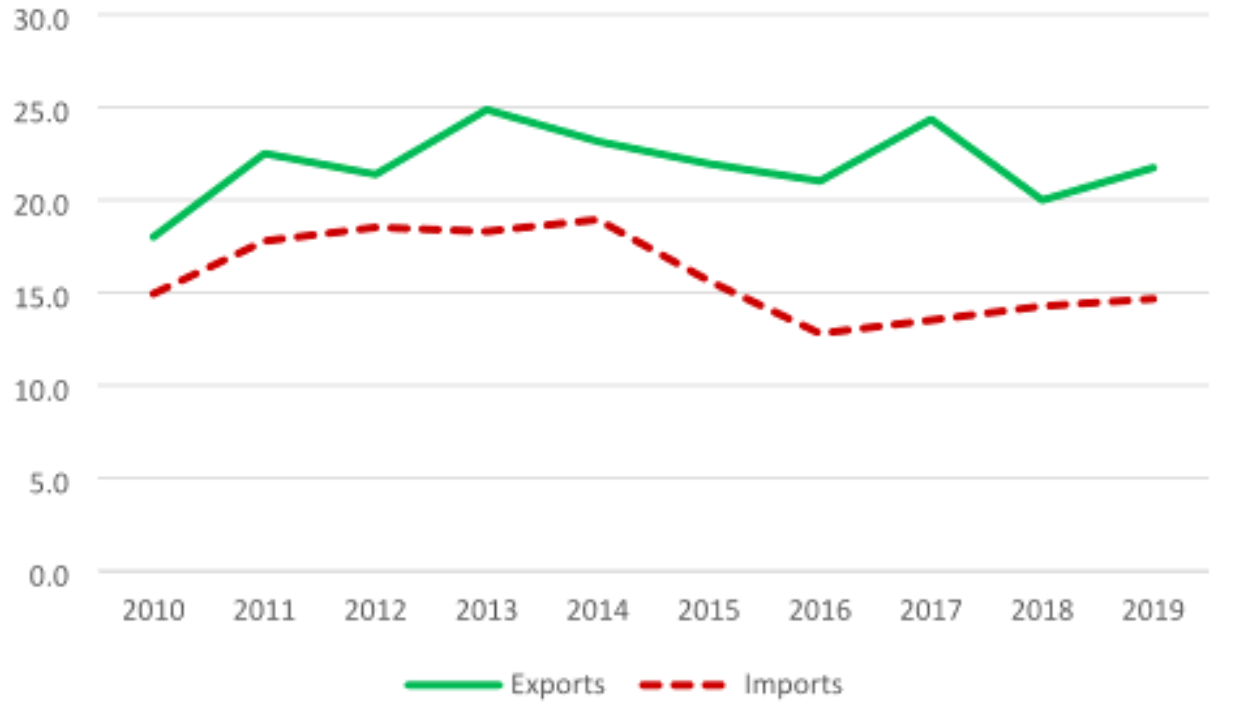

Figure 3

a: Intra-regional trade among West Africa countries (\%)

Source: Computed from IMF Direction of Trade Statistics

Figure 4

Africa regional real GDP per capita growth rates (\%)

Source: World Development Indicators, November 2020

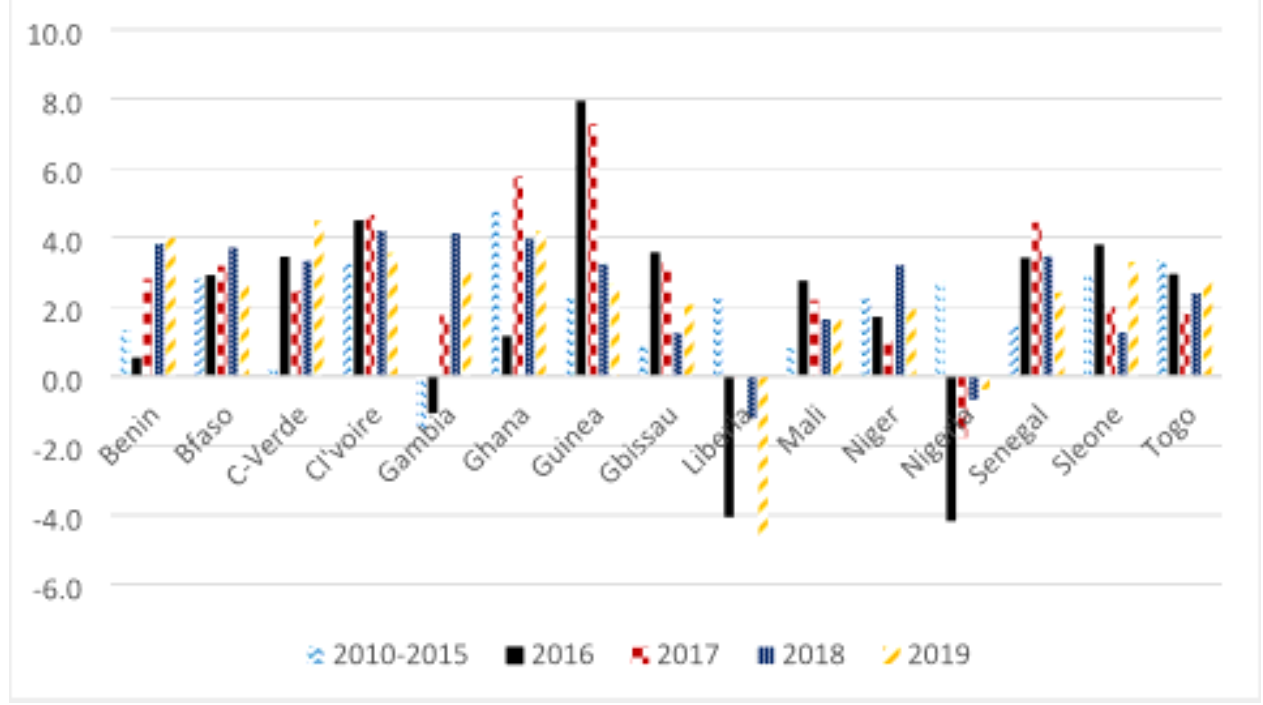

Figure 5

Real GDP growth rate in West Africa 
Source: World Development Indicators, November 2020

\section{Supplementary Files}

This is a list of supplementary files associated with this preprint. Click to download.

- TABLES.docx 